\title{
SPATIO-TEMPORAL CHARACTERISTICS OF THE BLUETONGUE EPIZOOTY IN THE BALKAN PENINSULA FROM 2014 TO FEBRUARY 2015
}

\author{
Zharko Stojmanovski ${ }^{1}$, Blagojcho Tabakovski ${ }^{2}$ \\ ${ }^{1}$ Food and Veterinary Agency, Inspection Department, 11 Oktomvri str. bb, \\ Branch Office, 1300 Kumanovo, Republic of Macedonia \\ ${ }^{2}$ Food and Veterinary Agency, Animal Health and Welfare Department, 3-ta Makedonska \\ Brigada 20, 1000 Skopje, Republic of Macedonia
}

Received 16 March 2017; Received in revised form 14 September 2017; Accepted 8 November 2017

\begin{abstract}
Starting in May 2014 an emerging Bluetongue (BT) serotype 4 (BTV-4) epizooty has affected the ruminant population of eleven countries from the Balkan Peninsula. Consequently, the veterinary services implemented various bio-security measures and a considerable discussion has been raised if future BTV surveillance and preventive measures should be taken in risk based zones and periods. Therefore, the objective of this work was to describe the spatial and temporal characteristics of the BTV-4 epizooty in the Balkan Peninsula from May 2014 to February 2015. We used the space-time permutation model of the scan statistic to identify the space-time disease clusters. The scan statistic was parameterized to a maximum temporal length of 150 days (duration of the epizooty in the Balkans in 2014) and a radius of $100 \mathrm{~km}$ as a maximum spatial cluster size (protection zone for BT). Results were significant $(\mathrm{p}<0.05)$ to the maximum spatial size defined for the clusters. From the 6295 BT outbreaks the scan statistics identified 33 disease clusters in nine Balkan countries. The highest number of outbreaks occurred from September to November 2014.The earliest cluster was detected in Greece in July 2014 with a radius of $56 \mathrm{~km}$. The latest cluster was detected in Croatia in February 2015 with a radius of $99,8 \mathrm{~km}$. These results are a first description of the spatial and temporal characteristics of the 2014-February 2015 BT epizooty in the Balkans.
\end{abstract}

Key words: bluetongue, space-time clustering, scan statistic, Balkans, surveillance, epizooty

\section{INTRODUCTION}

Bluetongue (BT) is a a non-contagious, vectorborne disease in ruminants caused by a bluetongue virus (BTV) and transmitted by the biting midges of the Culicoides spp. Currently, there are 26 known BTV serotypes (1). Hosts of the infection are domestic and wild ruminants, mainly sheep, followed by goats and cattle (2).

The first BT outbreaks (serotype 4, BTV-4) in South-East Europe were reported in 1979 on several Greek islands near the Anatolian Turkish

Corresponding author: Zharko Stojmanovski, DVM

E-mail address: zarkostojmanovski@yahoo.com

Present address: Food and Veterinary Agency of Republic of Macedonia,

Inspection Department, Branch Office,11 Oktomvri str. bb, 1300 Kumanovo,

Republic of Macedonia

Phone: ++389 70409238

Copyright: (C) 2017 Stojmanovski Z. This is an open-access article published under the terms of the Creative Commons Attribution License which permits unrestricted use, distribution, and reproduction in any medium, provided the original author and source are credited.

Competing Interests: The authors have declared that no competing interests exist.

Available Online First: 29 December 2017

Published on: 15 March 2018

https://doi.org/10.1515/macvetrev-2017-0033 coast (3). From then on, surveillance and control measures were applied in the Greek islands in east Aegean Sea (from 1980 to 1991), and until summer 1998 there were no reports of clinical disease in these islands (4). However, from 1998 to 2005 at least six BTV strains belonging to five serotypes (BTV-1, BTV-2, BTV-4, BTV-9, and BTV-16) were found to circulate in the Mediterranean Basin $(5,6)$. During this period, the Balkan countries reported at least $2000 \mathrm{BT}$ outbreaks with however, two main epizooties; the first epizooty in 1999 in Greece (BTV-9/4/16) and Bulgaria (BTV-9); and the second epizooty in 2001, affecting Greece, Bulgaria (BTV1/9) and Macedonia, Serbia and Croatia (BTV-9) (7). BTV outbreaks were reported by Bulgaria in 2006. Greece reported BTV-16 outbreaks in 2008 (7). Additionally, from 2009 to 2012, Greece was the only country in the Balkans which reported BTV-1/4/8/16 outbreaks (8).

In 2014, the emergence of the BTV-4 epizooty dramatically spread among 11 Balkan countries, leaving a devastating effect on the animal health 
and the economies of the countries. These countries cover $838680 \mathrm{~km}^{2}$ area and hold a livestock population of more than 27 million sheep, 7 million goats and 7 million cattle (9).

The circulation of numerous BTV serotypes in the Mediterranean Basin of South-East Europe, as well as the extent of the spread of BTV-4 from 2014 to February 2015 in the Balkan Peninsula - shows the necessity of understanding the risk areas and time periods for an early alerting of BTV emergence (re-emergence).

Therefore, this work is the first extensive description of the BTV-4 epizooty from 2014 to February 2015 in the Balkan Peninsula. Using the date of observation of the clinical signs of BT and the space-time permutation model of the scan statistic, this work presents the main risk zones and periods of BT occurrence in the Balkans.

\section{MATERIAL AND METHODS}

\section{Study area and study period}

From 29/05/2014 to 28/02/2015, BTV-4 outbreaks were reported by 11 Balkan countries, i.e. Greece, the European part of Turkey, Bulgaria, Macedonia, Albania, Serbia, Montenegro, Croatia, Bosnia and Herzegovina, Romania and Hungary.

\section{Data sources}

In order to identify the space-time clusters, we collected the data for the BT outbreaks reported to the World Animal Health Information System (WAHIS) of the World Animal Health Organization (OIE) (10). We freely downloaded the data regarding the country, administrative region, and location, date of observation of the first signs and the date of reporting of each of the BT outbreaks.

From a total of 6295 outbreaks, 3651 outbreaks had no information about the date of observation of the first signs of BTV-4. In such cases, we used the reporting date as a reference date. Eight outbreaks in Montenegro had no information about the BTV serotype and therefore were excluded from analysis. Overall, in this work we used all available data for the BTV-4 outbreaks, i.e. $42 \%$ of the outbreaks with known observation date and $58 \%$ of the outbreaks with a known reporting date.

\section{Data analysis}

Developed in 2001 by Kulldorff (11), the spacetime cluster analysis has been used for a variety of health issues, including outbreaks of emerging and vector-borne diseases, such as Avian Influenza, West Nile virus, Malaria, and Dengue fever (11). Space-time scan statistics are suitable for temporal historical data, in particular for a large amount of data, accumulated in space and time. Additionally, the outputs are easy to understand and interpret (12).

The space-time cluster analysis requires only outbreak data, with information about the spatial location and time for each outbreak. The number of observed outbreaks in a cluster is compared to what would have been expected if the spatial and temporal locations of all outbreaks were independent of each other, so that there is no space-time interaction. This is so, because there is a cluster in a geographical area if, during a specific time period, that area has a higher proportion of its outbreaks in that time period compared to the remaining geographical areas. This allows the space-time cluster analysis to identify not only the centre and the radius of a primary cluster (hotspot), but also specifies a time window when the clusters of new outbreaks are present (11).

The space-time cluster analysis requires several parameters:

i) a time aggregation period, which we have set to a 7-day time aggregation, because once an initial disease outbreak is reported to the OIE, countries send weekly reports to the OIE;

ii) a maximum size of the temporal window, which we have set up to 150 days, which was the maximum duration of continued detection of outbreaks notified to the OIE in 2014;

iii) a maximum extension of the spatial window, which we have set up to a radius of $100 \mathrm{~km}$, assuming to represent a cluster of outbreaks due to local, rather than long distance, disease transmission and spreading (13).

Space-time cluster analysis (permutation model) was performed with R SaTScan package which provides an automatic link to the SaTScan software. The statistical analysis was done using Statistica 7 software (14). Data visualisation was made with Q-GIS (15). The values of $\mathrm{p}<0.05$ were considered as statistically significant.

\section{RESULTS}

\section{Bluetongue epizooty}

From May 2014 to February 2015, a total of 6295 BTV-4 outbreaks were reported in the study area with 108.300 cases. Greece reported 2698 (42.8\%) of all outbreaks, while Bosnia and Herzegovina only five BTV-4 outbreaks (0.08\%) (Fig. 1 and 2). 


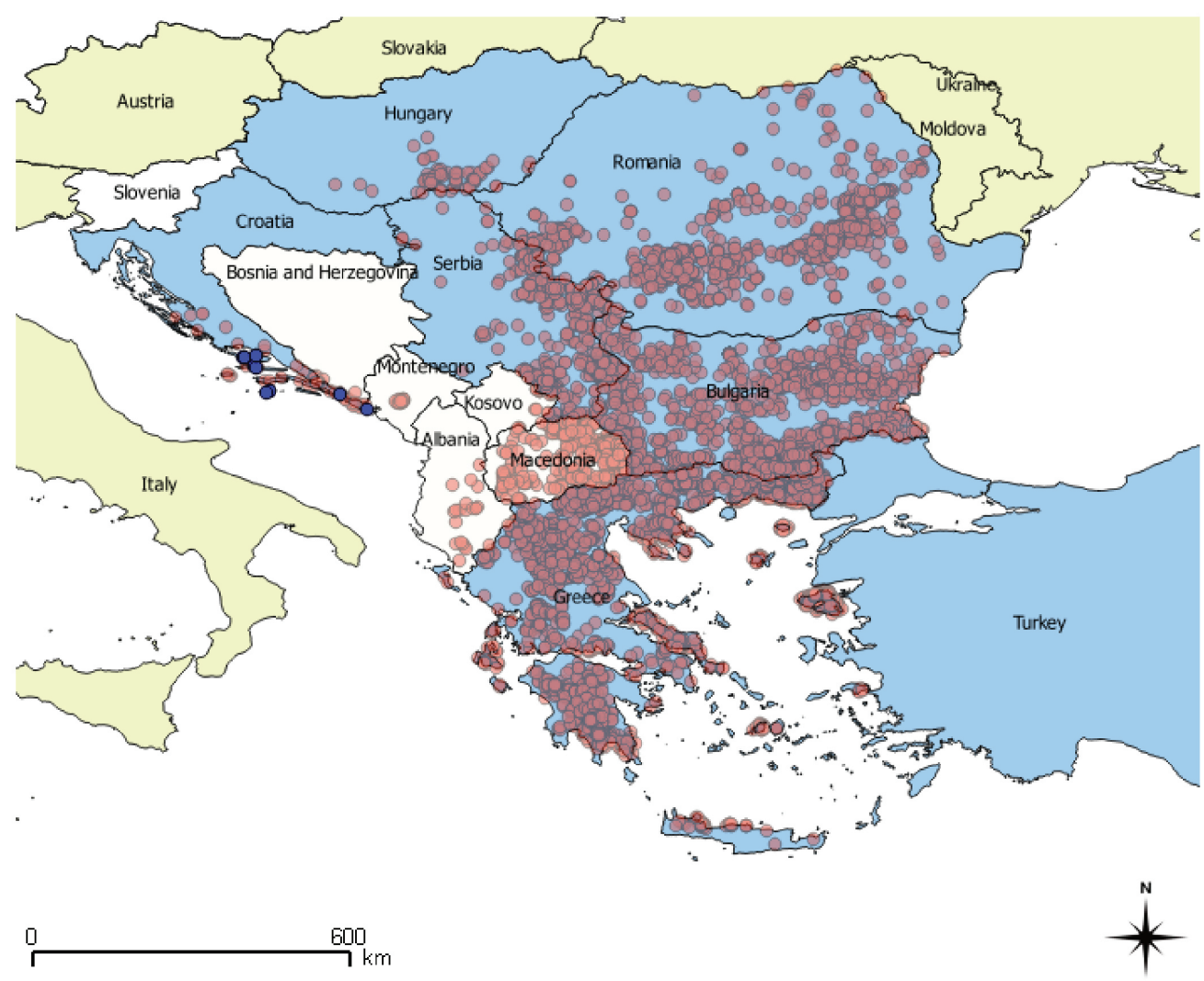

Figure 1. Spatial distribution of the BT outbreaks in 2014 (red points) and January-February 2015 (blue dots). The countries in blue refer to the countries which performed vaccination (either mandatory or voluntary) in 2015, Balkans countries with white colour refer to the countries with no-vaccination against BT

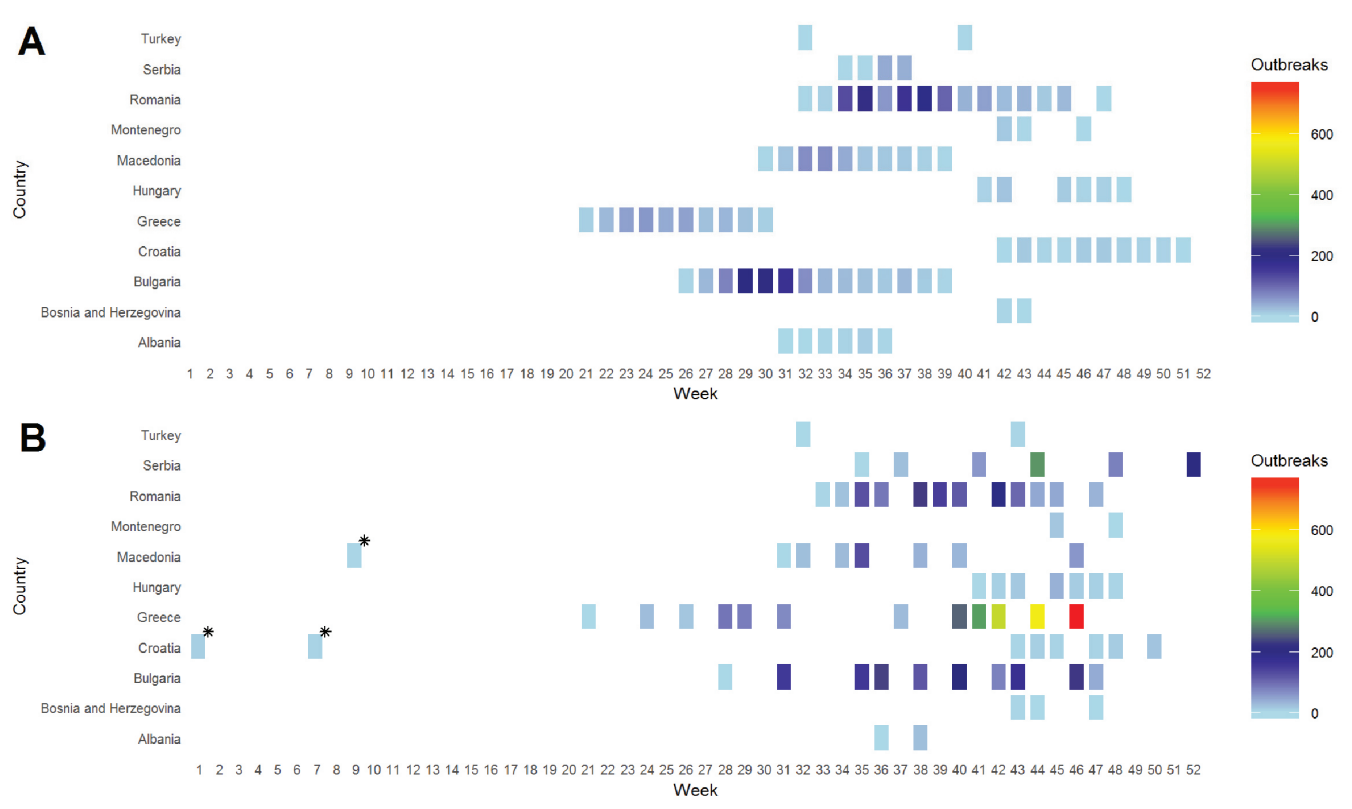

Figure 2. Number of outbreaks per week of observation of the clinical signs during the epizooty in 2014 (A). The number of outbreaks per week of reporting to the OIE. The stars indicate the outbreaks that were reported till February 2015 (B). 
The peak of the outbreaks was November 2014, with $2078(32.9 \%)$ reported and/or observed BT outbreaks (Fig. 2).

\section{Cluster identification}

During the BTV-4 epizootic in the Balkans, we identified in total 33 space-time clusters, among which 32 were statistically significant $(p<0.05)$ and non-significant cluster number $15(\mathrm{p}=0.23)$ (Table 1, Fig. 3)

Thirty two clusters were identified in 2014 and only one in February 2015 in the coast of Croatia (cluster number 33). The earliest BT disease cluster was identified in July 2014 in Peloponnese, Greece (cluster number 1) (Table 1, Fig. 3).

Table 1. Chronological order of BT space-time disease clusters in Balkans epizooty from 2014 to February 2015. The observed $(\mathrm{O})$ and expected $(\mathrm{E})$ number of outbreaks per cluster and the ratio $\mathrm{O} / \mathrm{E}$ are indicated

\begin{tabular}{|c|c|c|c|c|c|c|c|}
\hline $\begin{array}{l}\text { Cluster } \\
\text { number }\end{array}$ & Country & $\begin{array}{l}\text { Radis } \\
(\mathbf{k m})\end{array}$ & Start date & End date & $\begin{array}{l}\text { Observed/ } \\
\text { Expected }\end{array}$ & $\mathbf{O} / \mathbf{E}$ & $\begin{array}{l}\text { Duration } \\
\text { (days) }\end{array}$ \\
\hline 1 & Greece & 56 & 15.07 .14 & 16.07 .14 & $86 / 3,9$ & 22,1 & 2 \\
\hline 2 & Bulgaria, Greece, Turkey & 69,8 & 07.08 .14 & 08.08 .14 & $124 / 11,5$ & 10,6 & 2 \\
\hline 3 & Macedonia & 33,4 & 01.09 .14 & 05.09 .14 & $33 / 2,4$ & 13,8 & 5 \\
\hline 4 & Bulgaria, Turkey & 99,7 & 08.09 .14 & 08.09 .14 & $50 / 7$ & 7,1 & 1 \\
\hline 5 & Romania & 59,4 & 09.09 .14 & 09.09 .14 & $3 / 0,004$ & 750 & 1 \\
\hline 6 & Romania & 84,4 & 22.09 .14 & 23.09 .14 & $151 / 14,7$ & 10,3 & 2 \\
\hline 7 & Albania & 75,7 & 24.09 .14 & 24.09 .14 & $19 / 0,5$ & 38 & 1 \\
\hline 8 & Romania & 79,1 & 29.09 .14 & 29.09 .14 & $7 / 0,03$ & 233,3 & 1 \\
\hline 9 & Romania & 57,7 & 30.09 .14 & 03.10 .14 & $109 / 6,5$ & 16,9 & 4 \\
\hline 10 & Greece & 41,4 & 06.10 .14 & 06.10 .14 & $20 / 3,5$ & 5,7 & 1 \\
\hline 11 & Romania & 44,6 & 08.10 .14 & 08.10 .14 & $32 / 0,4$ & 80 & 1 \\
\hline 12 & Bulgaria, Romania & 61,2 & 10.10 .14 & 10.10 .14 & $90 / 6,5$ & 13,8 & 1 \\
\hline 13 & Greece-island of Lesbos & 10,9 & 13.10 .14 & 13.10 .14 & $58 / 4,2$ & 13,8 & 1 \\
\hline 14 & Greece & 69,8 & 13.10 .14 & 13.10 .14 & $94 / 15,5$ & 6,1 & 1 \\
\hline 15 & $\begin{array}{l}\text { Greece-island of Lemnos, } \\
\text { Turkey }\end{array}$ & 97,5 & 20.10 .14 & 20.10 .14 & $14 / 2,7$ & 5,2 & 1 \\
\hline 16 & Romania & 6,4 & 22.10 .14 & 22.10 .14 & $5 / 0,07$ & 71,4 & 1 \\
\hline 17 & Greece & 86,7 & 03.11 .14 & 03.11 .14 & $335 / 61$ & 5,5 & 1 \\
\hline 18 & Greece & 72,8 & 03.11 .14 & 03.11 .14 & $51 / 10$ & 5,1 & 1 \\
\hline 19 & Serbia, Bulgaria & 98,9 & 04.11 .14 & 04.11 .14 & $191 / 24,3$ & 7,9 & 1 \\
\hline 20 & Romania & 49,3 & 04.11 .14 & 04.11 .14 & $25 / 1,6$ & 15,6 & 1 \\
\hline 21 & Serbia, Romania, Hungary & 98,7 & 10.11 .14 & 13.11 .14 & $44 / 1,3$ & 33,9 & 4 \\
\hline 22 & Montenegro & 7,6 & 14.11.14 & 14.11 .14 & $15 / 0,06$ & 250 & 1 \\
\hline 23 & $\begin{array}{l}\text { Macedonia, Bulgaria, Greece, } \\
\text { Serbia }\end{array}$ & 95,3 & 17.11 .14 & 17.11 .14 & $106 / 8,01$ & 13,3 & 1 \\
\hline 24 & Bulgaria & 17,4 & 18.11 .14 & 18.11 .14 & $9 / 0,03$ & 300 & 1 \\
\hline 25 & Bulgaria & 0,00 & 20.11 .14 & 20.11 .14 & $25 / 0,1$ & 250 & 1 \\
\hline 26 & Greece & 29 & 21.11 .14 & 21.11 .14 & $165 / 32$ & 5,2 & 1 \\
\hline 27 & Greece & 99,9 & 21.11 .14 & 21.11 .14 & $78 / 13,2$ & 5,9 & 1 \\
\hline 28 & Cyprus & 83,4 & 21.11 .14 & 21.11 .14 & $33 / 6,1$ & 5,4 & 1 \\
\hline 29 & Greece-island & 27,1 & 21.11.14 & 21.11 .14 & $21 / 4$ & 5,25 & 1 \\
\hline 30 & Romania & 74 & 25.11 .14 & 25.11 .14 & $7 / 0,01$ & 700 & 1 \\
\hline 31 & Bulgaria & 21,6 & 26.11 .14 & 26.11 .14 & $26 / 0,2$ & 130 & 1 \\
\hline 32 & $\begin{array}{l}\text { Croatia, Bosnia and } \\
\text { Herzegovina }\end{array}$ & 84,2 & 19.12 .14 & 19.12 .14 & $14 / 0,1$ & 140 & 1 \\
\hline 33 & $\begin{array}{l}\text { Croatia, Bosnia and } \\
\text { Herzegovina }\end{array}$ & 99,8 & 13.02 .15 & 13.02 .15 & $5 / 0,01$ & 500 & 1 \\
\hline
\end{tabular}




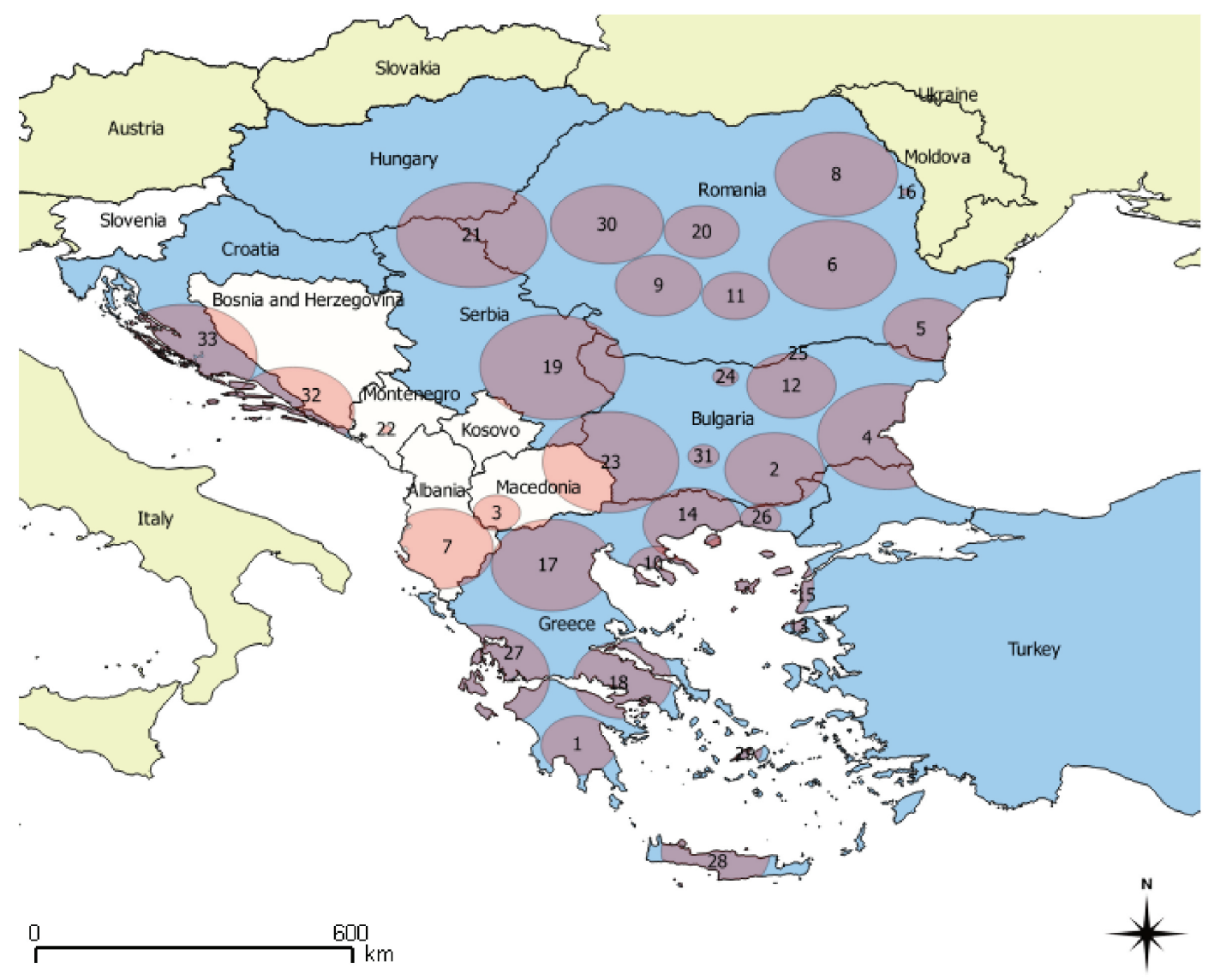

Figure 3. BT disease clusters (red circles) in the Balkans, detected from 2014 to February 2015 by use of the permutation model of the time- space scan statistic. The numbers refer to the designation of cluster presented in Table 1

In all detected clusters there occurred 3815 outbreaks, which represents $60.6 \%$ of the overall analysed 6295 outbreaks. The highest number of outbreaks was identified in the north-west of Greece, cluster number $17(\mathrm{n}=466,12.2 \%)$ radius $86.7 \mathrm{~km}$, which was identified in November 2014 and theleast in municipality of Ruse in Bulgaria, cluster number $25(\mathrm{n}=1,0.03 \%)$ radius less than 1 $\mathrm{km}$, which was identified also in November 2014.

In July and August were charaterised by the detection of one disease cluster, September and October by seven, while the monthly peak was identified in November ( $\mathrm{n}=15,45 \%$ ), with one cluster in December and the last one in February 2015. The median $\mathrm{O} / \mathrm{E}$ value was 250 with minimum $\mathrm{O} / \mathrm{E}=5.1$ and maximum $\mathrm{O} / \mathrm{E}=700$ values (Table 1 ).

The mean duration of the identified BTV-4 clusters was 1.39 days (range 1 to 5 days, median of 1 day). Twenty-seven of the clusters (82\%), were with a duration of 1 day (Table 1).

The Pearson's coefficient of correlation showed weak negative linear correlation between the radius of the disease cluster and the duration in days $(\mathrm{r}=-0.12 ; \mathrm{p}=0.51)$, and a weak positive linear correlation between the radius of the disease cluster and the observed cases $(r=0.28 ; p=0.12)$.

\section{DISCUSSION}

\section{Spread of the Bluetongue virus}

Our results show that the 2014 BTV-4 epizooty started at the south of Greece and spread rapidly through the Balkan countries. In contrast to the current BTV epizooty, the BTV9 epizooty in September 2001 started in the prefecture Ioannina in western Greece, and then spread to Albania, Macedonia, Kosovo, Bulgaria and Croatia (16).

Our results also suggest that the south-east parts of the Balkan Peninsula had a higher number of BTV-4 outbreaks compared to the north-west (17). In June 1999, the BTV-9 epizooty started in south-east Bulgaria, near the coast of the Black Sea 
and then spread to the west, and south in Greece (Rodopi and Evros regions) (16).

Our findings suggest that the epizooty started at the end of May 2014 in Greece and continued to spread in July in Bulgaria and Macedonia, in August in Serbia and Romania and in October in Croatia and Hungary.

Most of the clusters were identified from September to November 2014, which affirms that most of the BT infections occurred in late summer and autumn 2014 (September-November). However, due to the fact that for $58 \%$ of the outbreaks the observation date was unknown, these results might be biased, as a result of delayed reporting and missing information. A study in Serbia which investigated the BTV-4 outbreaks at a national scale, showed similarly that the peak of the outbreak was in September and October 2014 (18). In Macedonia, the last BT outbreak was reported at the start of November 2014 and no BTV viral circulation has been detected up to the end of study period (19).

Compared to the epidemiological analysis conducted by EFSA (20), which showed two peaks of case notification (August and October) in the 2006 BTV-6 epizooty, the BTV-4 epizooty in the Balkans had only one peak.

These results re-affirm the seasonality of BT in this part of Europe, which starts in spring and might extend by February of the following year. For comparison, the BTV-8 epizooty in northwestern Europe started in August 2006 in the Netherlands; the first occurrence of BTV-8 in the United Kingdom was in September 2007; identical to Sweden which declared its first outbreaks of BTV-8 in September 2008 (21, 22, 23).

In Europe, BT is characterized by strong seasonal variations in incidence, related to the seasonality of the vector population (24). The infections usually occur in late summer and autumn (25), largely because of environmental factors, such as humidity and temperature (26). Wind was also a significant contributor to the spread of the infection $(27,28)$. Our future works will be focused on modelling the influence of the animal demographic and bioclimatic conditions on the spread of BT in the Balkans.

\section{Bluetongue clusters}

Our findings suggest that BT clustered in 32 statistically significant hotspot areas, compared with the two clusters in North-West Europe during the BTV-8 epizooty in 2006. First disease cluster number 1 was identified in Greece in July 2014 with a radius of $56 \mathrm{~km}$.
During the 2006 BTV-8 epizooty in the northern Europe, the first cluster (Maastricht cluster in The Netherlands) was identified in August at a radius of $35 \mathrm{~km}$ which extended to $75 \mathrm{~km}$ by December 2006. The second cluster was identified in the North-West Belgium (Ghent cluster) in the middle of October with a maximum size of $21.6 \mathrm{~km}$ (20). In our study, the second cluster was identified in Bulgaria, 3 weeks after the first cluster in Greece. This cluster was identified in August, 2014 with a radius of $69.8 \mathrm{~km}$, and included both parts of Greece and Turkey.

In comparison, the four detected clusters in 2014 match with administrative areas affected by the BTV outbreaks in 1998 and 2002. Overlapping occurred in Bulgaria (1999, Burgas region) - cluster number 4, Greece-mainland (1999, Evros region) cluster number 2 and the Greek island Lesbos (October 1979) cluster number 13, Macedonia (2001, North-Eastern region-municipality Kriva Palanka) cluster number 23, Albania (2002, LibrazhdElbasan area) cluster number 7, and Croatia (2001, Dubrovnik-Neretva region) cluster number 32 (29). In September 1999, BTV-4 clusters in Greece were identified in the prefecture of Chalkidiki (16), which is similar to our findings (cluster 10 which was identified in October 2014).

It is an interesting fact that in 2013, there were no declared BT outbreaks neither in mainland nor island areas in the Balkans and Asian part of Turkey. The nearest affected areas were Italy and Sicily with BTV-1/2/16 on the west and the Gaza Strip BTV-2/4 on the east (6). It can be assumed that BTV-4 was circulating at a very low prevalence rate (possibly in livestock and/or wildlife) (30).

Finally, the identified clusters do not oblige authorities to target preventive measures within certain clusters, but allow them monitoring of specific regions in high risk areas and periods (31).

\section{CONCLUSION}

Our work can serve as guidance to governmental veterinary authorities to formulate animal health strategies to mitigate the spread of the disease through, vaccination, education campaigns, increased monitoring in targeted areas and interventions to improve biosecurity on the holdings. In addition, it is important to recognize timely and joint regional country actions, as vectors do not recognise frontiers. 


\section{CONFLICT OF INTEREST}

The authors declared that they have no potential conflict of interest with respect to the authorship and/or publication of this article.

\section{ACKNOWLEDGEMENT}

We thank Dr. Elena Arsevska for the given advice during the analysis and writing of this work. She was involved in the design of the study, provision of data, as well as revision of the final manuscript.

\section{REFERENCES}

1. Coetzee, P., Stokstad, M., Venter, E.H., Myrmel, M., Van Vuuren, M. (2012). Bluetongue: a historical and epidemiological perspective with the emphasis on South Africa. Virol. J. 9, 198.

https://doi.org/10.1186/1743-422X-9-198

PMid:22973992 PMCid:PMC3492172

2. OIE - World Organisation for Animal Health [Internet]. Technical disease cards. Last update: April 2013. [Accessed 02 April 2016].

http://www.oie.int/fileadmin/Home/eng/Animal_ Health_in_the_World/docs/pdf/Disease_cards/ BLUETONGUE.pdf

3. Vassalos, M. (1980). A case of bluetongue in the island of Lesbos (Greece). In: Bulletin de l'Office International des Epizooties. Presented at the 48. Session Generale du Comite de l' OIE [Office International des Epizooties]. 75 - Paris (France). 26-31 May 1980.

4. Nomikou, K., Mangana-Vougiouka, O., Panagiotatos, D.E. (2004). Overview of Bluetongue in Greece. Vet.Ita. 40 (3), 108-115.

PMid:20419645

5. Saegerman, C. (Ed.), (2008). Bluetongue in northern Europe. OIE, Paris.

6. OIE-BT-Labnet-Bluetongue Reference Laboratories Network. [Interent]. Instituto Zooprofilallatico Sperimentale dell Abruzzo e del Molise "G. Caporale" Campo Boaria, 64100 Teramo, Italy. [Accessed 01 November 2016].

http://oiebtnet.izs.it/btlabnet

7. OIE - World Organisation for Animal Health [Internet]. World Animal Health Service. Database Handistatus II [Accessed 02 April 2016]. http://web. oie.int/hs2/sit_mald_incid_pl.asp?c_mald=10\&c cont $=4$
8. OIE - World Organisation for Animal Health [Internet]. World Animal Health Service. [Accessed 17 April 2016].

http://www.oie.int/wahis_2/public/wahid.php/Diseaseinformation/statusdetail

9. FAO - Food and Agriculture Organization of the United Nations [Internet]. Statistic divisions. [Accessed 17 April 2016]. http://faostat3.fao.org/download/Q/QA/E

10. OIE - World Organization for Animal Health [Internet]. World Animal Health Service. Database WAHIS. [Accessed April 17 2016].

http://www.oie.int/wahis_2/public/wahid.php/Diseaseinformation/statusdetail

11. Kulldorff, M. (2015). SatScan user guide for version 9.4. Available from: www.satscan.org

12. Robertson, C., Nelson, A.T., MacNab, Y.C., Lawson, A.B. (2010). Review of methods for spacetime disease surveillance. Spatio and Spatio-temporal epidemiology 1, 105-116.

https://doi.org/10.1016/j.sste.2009.12.001

PMid:22749467

13. Commission of the European Communities. European Commission Decision of 20 November 2000 Implementing Council Directive 2000/75/EC Concerning the specific provisions for the control and eradication of bluetongue, Off $\mathrm{J}$ Eur Comm, 327, 22.12.200, p.74.

14. Statistica version 7. Software for statistical analysis. Available from: http://statistica.io/

15. QGIS. A free and open source geographic information system. Available from: www.qgis.com

16. Ducheyne, E., De Deken, R., Bécu, S., Codina, B., Nomikou, K., Mangana-Vougiaki, O., Georgiev, G., Purse, B.V., Hendrickx, G. (2007). Quantifying the wind dispersal of Culicoides species in Greece and Bulgaria. Geospatial Health 1, 177-189.

https://doi.org/10.4081/gh.2007.266 PMid:18686243

17. Kyriakis, C.S., Billinis, C., Papadopoulos, E., Vasileiou, N.G.C., Athanasiou, L.V., Fthenakis, G.C. (2015). Bluetongue in small ruminants: An opinionated review, with a brief appraisal of the 2014 outbreak of the disease in Greece and the south-east Europe. Vet. Microbiol. 181, 66-74. https://doi.org/10.1016/j.vetmic.2015.08.004 PMid:26304745

18. Djurić, S., Simeunović, P., Mirilović, M., Stevanović, J., Glavinić, U., Vejnović, B., Stanimirović, Z. (2017). Retrospective analysis of the bluetongue outbreak in Serbia. Mac.Vet.Rev 40 (1): 21-27. https://doi.org/10.1515/macvetrev-2016-0094 
19. Pinna, F.A., Romero, L. (2015). Mission of the community veterinary emergency team in the former Yugoslav Republic of Macedonia in relation to bluetongue situation. PAFF Committee 7-8th July 2015.

20. EFSA Panel on Animal Health and Welfare (2007). Report on epidemiological analysis of the 2006 bluetongue virus serotype 8 epidemic in northwestern Europe, EFSA Journal 2007; 5(4): RN-34, 366.

21. Saegerman, C., Berkvens, D., Mellor, P.S. (2008). Bluetongue epidemiology in the European Union. Emerg Infect Dis. 14, 539-544. https://doi.org/10.3201/eid1404.071441 PMid:18394269 PMCid:PMC2570923

22. Sternberg Lewerin, S., Hallgren, G., Elvander, M., Treiberg Berndtsson, L., Chirico, J., Mieziewska, K. (2010). Infection with bluetongue virus serotype 8 in Sweden in 2008. Vet. Rec. 167, 165-170. https://doi.org/10.1136/vr.c3380 PMid:20675625

23. Szmaragd, C., Wilson, A.J., Carpenter, S., Wood, J.L.N., Mellor, P.S., Gubbins, S. (2010). The Spread of bluetongue virus serotype 8 in Great Britain and its control by Vaccination. PLoS ONE 5, e9353. https://doi.org/10.1371/journal.pone.0009353 PMid:20179768 PMCid:PMC2825270

24. Foxi, C., Delrio, G. (2010). Larval habitats and seasonal abundance of Culicoides biting midges found in association with sheep in northern Sardinia, Italy. Med. Vet. Entomol. 24, 199-209. https://doi.org/10.1111/j.1365-2915.2010.00861.x PMid:20604864

25. Guis, H., Caminade, C., Calvete, C., Morse, A.P., Tran, A., Baylis, M. (2012). Modelling the effects of past and future climate on the risk of bluetongue emergence in Europe. J. R. Soc. Interface 9, 339-350. https://doi.org/10.1098/rsif.2011.0255 PMid:21697167 PMCid:PMC3243388

26. Guis, H., Tran, A., De La Rocque, S., Baldet, T., Gerbier, G., Barragué, B., Biteau-Coroller, F., Roger, F., Viel, J.-F., Mauny, F. (2007). Use of high spatial resolution satellite imagery to characterize landscapes at risk for bluetongue. Vet. Res. 38, 669-683. https://doi.org/10.1051/vetres:2007025 PMid:17583664
27. Hendrickx, G., Gilbert, M., Staubach, C., Elbers, A., Mintiens, K., Gerbier, G., Ducheyne, E. (2008). A wind density model to quantify the airborne spread of Culicoides species during north-western Europe bluetongue epidemic, Prev. Vet. Med. 87(1-2): 162181.

https://doi.org/10.1016/j.prevetmed.2008.06.009 PMid:18639355

28. Faes, C., van der Stede, Y., Guis, H., Staubach, C., Ducheyne, E., Hendrickx, G., Mintiens, K. (2013). Factors affecting bluetongue serotype 8 spread in Northern Europe in 2006: The geographical epidemiology. Prev. Vet. Med. 110, 149-158. https://doi.org/10.1016/j.prevetmed.2012.11.026 PMid:23273733

29. Panagiotatos, D.E. (2004). Regional overview of bluetongue viruses, vectors, surveillance and unique features in Eastern Europe between 1998-2003. Vet. Ital. 40(3): 61-73.

PMid:20419637

30. Sailleau, C., Bréard, E., Viarouge, C., Vitour, D., Romey, A., Garnier, A., Fablet, A., Lowenski, S., Gorna, K., Caignard, G., Pagneux, C., Zientara, S. (2015). Re-emergence of bluetongue virus serotype 8 in France, 2015. Transbound Emerg Dis. 64, 9981000 .

https://doi.org/10.1111/tbed.12453

PMid:26617414

31. Iglesias, I., Perez, A.M., De la Torre, A., Mu-oz, M.J., Martínez, M., Sánchez-Vizcaíno, J.M. (2010). Identifying areas for infectious animal disease surveillance in the absence of population data: Highly pathogenic avian influenza in wild bird populations of Europe. Prev. Vet. Med. 96, 1-8. https://doi.org/10.1016/j.prevetmed.2010.05.002 PMid:20537421 